University of Nebraska - Lincoln

DigitalCommons@University of Nebraska - Lincoln

2015

\title{
"Fighting over a Shadow?": Hellenistic Greek Cities and Greco-Roman Cities as Fora and Media for Multi-Level Social Signaling
}

LuAnn Wandsnider

University of Nebraska-Lincoln, lwandsnider1@unl.edu

Follow this and additional works at: http://digitalcommons.unl.edu/anthropologyfacpub

Part of the Archaeological Anthropology Commons, and the Classical Archaeology and Art History Commons

Wandsnider, LuAnn, "'Fighting over a Shadow?": Hellenistic Greek Cities and Greco-Roman Cities as Fora and Media for Multi-Level Social Signaling" (2015). Anthropology Faculty Publications. 66.

http://digitalcommons.unl.edu/anthropologyfacpub/66

This Article is brought to you for free and open access by the Anthropology, Department of at DigitalCommons@University of Nebraska - Lincoln. It has been accepted for inclusion in Anthropology Faculty Publications by an authorized administrator of DigitalCommons@University of Nebraska Lincoln. 


\title{
"Fighting Over a Shadow?": Hellenistic Greek Cities and Greco-Roman Cities as Fora and Media for Multi-Level Social Signaling
}

\author{
LuAnn Wandsnider
}

\section{Introduction}

Historical accounts emphasize intra-individual competition among the citizenry of Hellenistic cities and Greco-Roman cities of Anatolia. ${ }^{1}$ These and other historical accounts emphasize the strife and rivalries occurring between cities. ${ }^{2}$ Aelius Aristides labelled this intra-city strife a "madness," representing "fighting over a shadow" that annoyed the emperor. ${ }^{3}$ Subsequent analysis has demonstrated, however, that these intra-city competitions were much more substantial and consequential. ${ }^{4}$ In this chapter, I use signaling theory to link rivalries at the citizen and city levels and explore the role played by monumental civic architecture as employed by citizens and cities to communicate with their rivals. Citizens signaled to other citizens their prosocial orientation as well as their oratorical ability and wealth with which they could act on this orientation. Cities signaled to their peers and superiors their pro-superior inclination and their abilities to mount significant collective action.

This chapter presents signaling theory as a higher-level body of evolutionary theory that sees early urban formations, i.e., cities, as both the fora and media for emergent complex social interactions, allowing both citizens and cities to be differentially "successful." I first introduce multi-level social signaling and then attempt to argue for the public architecture seen in the Greek cities of Hellenistic western Anatolia (third through first centuries BC) and Greco-Roman cities of Roman Asia Minor (first through third centuries AD) as a conjoined costly signal emitted by both citizen and city. Finally, I reexamine several propositions about the complex social interactions in these cities,

1 E.g., Greek and Roman overview in Veyne 1976; see also Price 1984.

2 Gleason 2006; Mitchell 1993.

3 Aelius Aristides, Oration 23.59, 62-64.

4 Burrell 2004; Millar 1993. 
adding, I hope, to current efforts to construct a broader yet nuanced understanding of ancient cities.

\section{Multi-Level Social Signaling}

Signaling theory refers to a subset of Darwinian thinking that describes the non-lethal communication that occurs between entities (i.e., individuals and groups), with the communicative act itself linking observable and unobservable traits. In the case of human actors, a material act communicates some hidden aspect of an individual or group, and, with this signal, other discerning entities (or receivers) can make decisions about whether to engage with, ally with or avoid the signaler. Indeed, the allegiances and alliances constitute one kind of acknowledgement of the signal quality by other individuals (in the case of an individual signaler) or by other groups (in the case of a group signaler). Decisions about with whom to ally have immediate consequences for success in reproduction, production, and social production. Families make decisions about whether to ally their families by marrying sons and daughters, by agreeing to farm together, and by agreeing to defend their community, thus affecting their mutual survival. Within an evolutionary framework, a good decision is one that leads to success for allied senders and receivers, where success is defined as persistence and perhaps even expansion. By definition, a bad decision may lead to familial or group extinction.

Anthropologists Bleige Bird and Smith (2005) reviewed signaling theory, finding it useful for incorporating disparate concepts-Thorstein Veblen's (1994; first published 1899) notion of conspicuous consumption and Pierre Bourdieu's (1986) notion of social capital-into a single evolutionary framework. By doing so, behaviors that at first glance seem to serve no functional end and appear irrational now have a rational basis. In this way, social science investigative tools can be brought to bear on the seemingly irrational. ${ }^{5}$

Fraser Neiman (1997) was the first to apply this approach in anthropology, with his analysis of Classic Mayan pyramids and stelae ${ }^{6}$ as costly signals emitted by lords and would-be lords. He argues that the so-called Maya collapse, that is, the cessation of pyramid building and stelae erection seen in the Maya

5 Costly signaling, a flavor of signaling, was first discussed in the biological literature as the handicap principle. See Grafen 1990, Zahavi 1975, Zahavi and Zahavi 1997. See Cronk 2004 and Higham 2014 for recent correctives. See also Smith and Bleige Bird 2000.

6 Stelae (singular stela) are intricately carved upright slabs of stone found both within communities and at borders and used to project political messages, Borowicz 2002. 
heartland about AD 9oo, is best interpreted as a cessation in signaling as the potential audience for these costly signals fled to areas where agricultural potential had not been reduced by locally high rainfall levels. Signalers had too few receivers to whom to send, he contends.

Shortly thereafter, James Boone $(1998,2000)$ focused analytic attention on magnanimity, that is, generous community feasts sponsored by specific kin groups, as another kind of costly signal. He argued that these constituted a way for middle-range groups with dynamic kin groups (his examples came from ethnographically known American Northwest Coast complex huntergatherers and American Southwest agriculturalists) to build status. In turn, this status was used to establish priority access to resources when times were bad. $^{7}$

Why the term, "costly signaling?" What is "costly" about a costly signal? In Zahavi's (1975) earliest conceptualization, the idea was that low cost signalers emitting a high cost signal were more handicapped than a high quality signaler sending the same signal; this marginal cost ensured an honest signal, Zahavi argued.

This initial conceptualization has not stood the test of time. More recent analyses ${ }^{8}$ have recognized that Zahavi's costly signals need not be honest. This scholarship recognizes that some honest signals may simply index a scalar quality of the signaler. In Neiman's Mayan case, only an individual with the skills, charisma, connections, and resources can actually put up a pyramid. Pretenders would soon be exposed. Similarly, in Boone's case, the feast is an honest index of kin network size and organization. In addition, signals passed between senders and receivers may expose the circumstances under which their interests are aligned or misaligned, as seen in the intra-citizen and intra-city analyses below.

For the purposes of this discussion, I focus on costly 'indexical' signals; that is, costly expenditure that acts as an index of hidden assets, like social network size, in the case of an individual, or ability to mount collective actions, in the case of a group. In addition to quality, signals have other properties. Like the Olympian games, they may occur intermittently, showcasing a signaler's strength and adeptness. Or, like religious festivals, they may be

7 In archaeology, other applications of this thinking have followed. See McGuire and Hildebrandt (2005) and Plourde (2008) for application to prehistoric hunter-gatherers; Glatz and Plourde (2011) use Costly Signaling Theory in their analysis of Hittite frontier stelea. Elsewhere, I (Wandsnider 2013) have used this approach to look at public benefactions in Roman Western Rough Cilicia.

8 Summary in Higham 2014. 
broadcast annually, allowing families to reassert their claims to status. ${ }^{9} \mathrm{Or}$, like fortification walls, they may be broadcasting continuously..$^{10}$ Signals may be transmitted over short distances, requiring person-to-person interaction, ${ }^{11}$ carry well within the community (as within the amphitheater, see Gleason's [2006] and van Nijf's [1997] discussion of social interactions in the amphitheater), or travel well over large distances as seen for the almost monumental circuit wall at Heraklea under Latmos. ${ }^{12}$ Other aspects of material signals are presented in the section that follows.

Finally, as already alluded to above, signals may be emitted by individuals or by groups. To date, most of the costly signaling literature has focused on signaling by either individuals to other individuals or between groups, such as kin groups. In a critical recent treatment, however, Paul Roscoe (2009) offers a compelling analysis of what he terms social signaling that links signaling at the individual and group levels. His analysis mines ethnographic accounts for contact-era New Guinea, where the competition for territory and organization of defense rivals that described for Hellenistic Anatolia. ${ }^{13}$ Individuals signal their capacities within social groups through ritualized competitions that put on display the qualities—stamina, courage, strength, mental agility—needed for successful competition at the group level. All contestants survive the contest and live to fight for the group another day. And individuals and families accordingly decide whom to support.

At the group level Roscoe recognizes social signaling in three forms: conspicuous distributions (lavish feasts), conspicuous performances by well-choreographed, intricately costumed performers, and conspicuous constructions (gigantic clan cult houses). Importantly, in both performances and the massive cult houses, the contributions of the individual are masked. All three media, however-material, performance, and architecture-communicate honest signals of the number of kin and allies supporting collective projects, the abilities of contributing individuals, and the fact that individuals are willing to bend their interests to a larger communal effort. That is, they are an index of collective action. ${ }^{14}$ In this manner, individual clans composing a village

$9 \quad$ Boone 1998.

$10 \quad$ Van Dyke and Alcock 2003.

11 As in daily bathing, for example; see Fagan 2002.

12 Camp 2000, 43.

13 Ma 2000.

14 Roscoe 2009, 98 also recognizes another kind of non-indexical signal that may allow for prevarication. Some groups may be so effective in manipulating their media that through aesthetics, they can present an image of power and danger that is not matched by actual strength. 
communicated with each other and villages communicated with other villages, especially important for maintaining territory in contact-era New Guinea.

This multi-level aspect of costly or social signaling is not insignificant. It helps resolve a paradox of social living that has long been recognized and commented upon by thinkers as diverse as Plato (The Republic), Aristotle (The Politics ), ${ }^{15}$ Ibn Khaldun (1958), and Charles Darwin (1922). That is, in a group of individuals with no other constraints, the selfish individual will outcompete the individual who thinks of others, that is, the altruist or, more aptly, the solidarist. But, in a world consisting of other groups competing for territory or other scarce resources, the group composed of solidarists (who are rewarded for their solidarity) will outcompete the group composed of selfish individuals.

Several points are critical here. Signaling between individuals occurs in a group that includes multiple signalers and also many receivers. Similarly, signaling between groups only matters if there are groups jockeying for position with a region of groups. That is, signaling is always a multi-level phenomenon. Second, signaling theory helps us to understand the individual-group-region dynamic. It helps us understand how competent individuals and groups are identified. Most importantly, it helps us understand the existence of large groups of unrelated but prosocial individuals, which challenges the conclusion reached through kin selection thinking ${ }^{16}$ _ that we help the people to whom we are related and, in so doing, help ourselves. ${ }^{17}$ On a competitive stage (and all of the world is such a stage), groups composed of solidarist individuals prevail. ${ }^{18}$

\section{Public Architecture as Costly Signals}

As mentioned above, social signals have various properties and here I focus expressly on public architecture as a material signal. More specifically, I suggest that public architecture seen in urban Hellenistic Anatolia and Roman Asia Minor, constructed through individual munificence as well as with city revenues, may usefully be viewed as a conjoined costly signal, emitted by both individuals, i.e., citizens, and the group, i.e., the polis or city. ${ }^{19}$

\footnotetext{
15 See Simpson 1997.

16 See Trivers 1971.

17 Much ink has been spilled on this issue in evolutionary biology. See Bowles and Gintis 2003, Boyd and Richerson 1992, Gintis et al. 2001, Heinrich 2006, Richerson et al. 2003, and Smith 2003 .

18 O'Gorman et al. 2008; Wilson and Wilson 2008.

19 So, as Alcock $(2002,19)$ notes, architectural materials already reported by archaeologists
} 
Certainly others have appreciated the signaling capacity of architecture, as Smith (2011) reviews. Bruce Trigger (1990), for example, focuses on monumental architecture, defined as those structures that exceed in scale and degree of elaboration that required by their functional role. He sees monumental architecture as a symbol of power, in that it is an egregious "expense of energy, especially in the form of other people's labour, in non-utilitarian ways." ${ }^{20}$ For him, the larger or more elaborate the structure, the greater the display of power, although Marcus (2003) cautions against taking this generalization as law. Trigger and also Abrams (1989) note that public architecture is particularly potent in conveying messages to linguistically and ethnically diverse groups, such as those commonly making up the populace of early and later states, and, as in the case here, Greek (and Greco-Roman) cities from the late Hellenistic period onward.

Several researchers ${ }^{21}$ have observed that public architecture seems often to have been constructed in stressful (but not catastrophic) times, such as in the initial phase of a new social, political, or economic formation. Abrams interprets this pattern in terms of the deliberate formation of a group identity; a signaling interpretation emphasizes that individuals, sub-groups, and groups are asserting not only identity so as to differentiate "us" from "them," but, as importantly, materially signaling their competence and capability to attract and maintain continuing support. And commenting on public architecture in the Valley of Oaxaca, archaeologist Richard Blanton notes: "As communications media, monumental architecture is actually relatively efficient. The initial costs of construction may be great, but once built a massive building or plaza can be seen by thousands of people over great lengths of time, broadcasting continuously for even thousands of years."22 Elsewhere, Blanton (1994) recognizes different kinds of communication or signals: indexi$\mathrm{cal}$, to indicate relative status (communicating with peers), and canonical, to indicate participation in a broader cultural tradition (a supra-ordinate audience).

Architecture as a signal is specifically referenced in the literature on costly and social signaling. Neiman (1997) argues that potential lords incurred personal costs in the construction of pyramids and stelea, which informs non-kin

and others become the grist for various interpretative efforts. Where Alcock emphasizes assertions of social memory through architecture, I shift focus to a more general communicative aspect of public architecture.

20 Trigger 1990, 125.

21 Abrams 1989; Childe 1945.

22 Blanton 1989, 413. 
especially on their leadership qualities. Where for Neiman buildings are used as indices of personal abilities, Roscoe (2009) sees them, in the case of the cult houses constructed by southern lowland New Guinea clan groups, as a means for indexing effective collective action, wherein actions of individuals are sublimated to the group cause.

It seems potentially useful, then, to consider public architecture as a signal, but important questions remain: who is the signaler? whom is being signaled? is the public architecture signal indeed a costly signal? what message is being conveyed? To answer these questions for the Greek cities of Hellenistic Anatolia and the Greco-Roman cities of Roman Asia Minor, I rely on several recent treatments of civic benefactions as known through epigraphic inscriptions.

\section{Public Architecture as an Individual Costly Signal}

In the case of the Greek cities of Anatolia during the Hellenistic era, public buildings were one of several kinds of civic benefaction made by the dynasts and Successor kings vying for control of territory and tribute in the power vacuum left by Alexander. ${ }^{23}$ As wealth increased during the later Hellenistic period, wealthy citizens replaced dynasts and would-be dynasts as the civic benefactors. In a recent thesis on aedilitian ${ }^{24}$ euergetism for Hellenistic western Anatolia, Marest-Caffey (2008) notes the transition from short acknowledgements of civic benefactions to, in the late Hellenistic era, lengthy detailed accounts of the grooming and benefaction histories of individuals from wealthy families. These polis notables, we learn, underwrote city deficits, ensured the availability of grain in times of scarcity, built or repaired city buildings, and headed up diplomatic missions to other cities, local dynasts, or the Roman Senate itself. ${ }^{25}$ In some cases, the wealthy notables assumed various city offices or magistracies, which were at this time undergoing a transition from democratically elected offices to offices bought and held for life by the wealthy. ${ }^{26}$

The perspective emphasized in the literature on euergetism or public benefaction is that of individuals performing and having acknowledged in inscriptions their virtuous qualities. ${ }^{27}$ The costly signaling perspective would regard

\footnotetext{
23 Veyne 1976.

24 Following European scholarship, Marest-Caffey $(2008,10)$ distinguishes aedilitian euergetism as that involving benefactors who restored, repaired, embellished, and erected public buildings, among the most costly and visible of benefactions.

25 Gauthier 1985; Migeotte 1997.

26 Dmitriev 2005; Quaß 1993.

27 Gauthier 1985; Migeotte 1997; Veyne 1976; Zuiderhoek 2009.
} 
these acts as signals with a larger purpose. That is, these acts convey information about individual qualities that assists others in making good decisions about potential leaders and allies. What might some of these qualities have been? One might be effectiveness as a member of the many diplomatic embassies sent first to the Successor kings and local dynasts as well as to other cities, ${ }^{28}$ potential Roman patrons, ${ }^{29}$ to the Roman Senate and still later to the Roman governors and emperors. ${ }^{30}$ That is, an individual who is able to negotiate with various forces and factions within the city for the placement of a building or the organization of a festival likely also possesses the oratorical and persuasive skills to be effective in Rome. A second quality conveyed is that of being able to organize and finance the religious festivals that were the life of the Anatolian city. ${ }^{31}$ Again, the individual citizen is communicating in deed their prosocial orientation as well as their financial ability. A final quality might be that of being able and inclined to pay ransom for kidnapped citizens, especially when pirates and brigands were active, as they were during the late Hellenistic period in the Mediterranean. ${ }^{32}$

Where for the later Hellenistic Period individuals may be seen as signaling their prosocial orientation to the demos and the oligarchs, in Imperial times wealthy citizens appear to be signaling other oligarchs for entrance into the ranks of the bouleutic order ( $\grave{a}$ la Veblen's analysis of the nouveau riche in the late-nineteenth-century United States). In a recent masterful treatment for Roman Asia Minor Arjan Zuiderhoek examines the institution of civic benefactions using a database compiled from inscriptions acknowledging more than 500 acts, including constructing whole or portions of public buildings, underwriting the distribution of food, and sponsoring religious festivals and games. By this time, Asia Minor cities were governed by an oligarchy, with elite families dominating the council and other political offices. ${ }^{33}$ As well, the composition of council was likely very dynamic, owing to simple demographic factors. ${ }^{34}$ City councils, composed of hundreds of people, undoubtedly lost many people each year through natural causes. Who should replace them? In this situation, Zuiderhoek contends that the benefactions of the potential office-holders were used by the elites in power to identify whom to grant entrance.

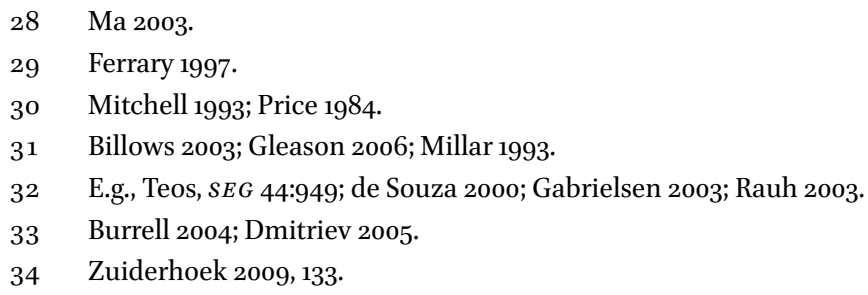




\section{Public Architecture as a Group Costly Signal}

In addition to being viewed as an individual signal, public architecture is also usefully seen as a signal emitted by "the city." The polis assembly and council, usually in tandem, are making decisions about the location, nature, and scale of public building. ${ }^{35}$ While the benefactions of wealthy individuals are responsible for some of these buildings, recent scholarship ${ }^{36}$ emphasizes $^{2}$ that city institutions also called upon revenues from rent, liturgies, and indirect taxes to finance public building. And, importantly, the city may have solicited subscriptions from citizens and others (women and foreigners, for example) to finance the construction of large buildings. ${ }^{37}$ This latter is important for it conveys that individuals, either under duress or willingly, sublimated their individual effort to a communal effort.

The messages and audiences for the city signal are several. City residents, both citizens and non-citizens, are receiving messages about the differential power of different city and, later, imperial institutions. Hansen and FischerHansen (1994), writing on Greek cities in Greece, note the changes in monumentality that occur over time, with monumental palaces and temples seen in Archaic and Classical times, and, by the Hellenistic period, monumental bouleuteria and prytaneia, i.e., monumental buildings associated with republican institutions. The presence, location, and scale of solidaristic public architecture - agoras, baths, gymnasiums, bouleuteria, odea, and theaters - communicate to citizens and potential citizens the solidarist orientation of the city; such messages may be especially important to the recruitment efforts of cities during the Late Hellenistic period when geographic mobility seems to have been quite high. ${ }^{38}$ Into the Imperial period, triumphal arches, statues and temples to the Imperial cult, as well as massive bathing complexes fed by aqueducts, signaled the presence and influence of emperor and, as importantly, the city's acknowledgement of the emperor. ${ }^{39}$ And, at least at Sagalassos, "[t]he open agoras and fora became enclosed, monumentalized spaces were designed to exclude rather than include and were dominated by buildings geared to

35 Raja 2003. The revised understanding of the council-assembly relationship sees the assembly, while perhaps with diminished power compared to earlier times, as more than a rubber stamp for council decisions and actions, even into the Imperial period. See Gauthier (1985), van Nijf (1997), and Zuiderhoek (2008).

36 Migeotte 1995; Reger 2003; Schwartz 2001; Zuiderhoek 2009.

37 Migeotte 1992, 1997.

$38 \quad$ Pomeroy $1997,108$.

39 Burrell 2004, 359-371; Mitchell 1993, 80; Price 1984. 
elite activity," as the oligarchic order was established and reified in architecture. ${ }^{40}$

Certainly, the residents of cities are paying attention to the cityscape, both form and upkeep, of potential polis allies (for the Hellenistic period) and competitors (for the Imperial period).$^{41}$ It is clear that at least in some instances, outside observers and decision-makers, such as agents of the Empire, paid careful attention to the constructions found in cities when deciding which city was worthy of being awarded the title of "neokoros."42 It remains to be established how the potential Successor kings of the Hellenistic era, pirates and brigands, and wealthy Roman patrons regarded and reacted to cityscapes of differently arrayed public splendor.

Indeed, the public architecture of the Hellenistic Anatolia and Roman Asia Minor appears to be a textbook example of what Bliege Bird and Smith ${ }^{43}$ refer to as "piggybacking," with costly signals of the city being deliberately assembled from the costly signals of individual citizens to the benefit of both. The citizen benefactor contributed (monumental) public buildings to the city, enhancing the signal emitted by the city. At the same time, the citizen is also rewarded by the polis in being named a euergetēs, with other difficult-to-assess rewardsaccess to the civic machinery or important social connections-presumably following. And, of course, the individual and his or her family benefits by virtue of being part of a successful communal unit, such as a city named first city, or to which the governor brings his assize, or that is excused from paying tribute. ${ }^{44}$

\section{Were Public Buildings “Costly Signals?” Do They Index Abilities?}

Public buildings constructed in Hellenistic and Roman times were certainly expensive. ${ }^{45}$ Do they in fact constitute an honest, costly signal, emitted by either the citizen or the city? That is, can they serve as a reliable index of collective action?

$40 \quad$ Waelkens 2002, 66.

41 “One could hold one's head up higher visiting another city if one's native city were known for its fine public buildings; it was painful to blush for ramshackle shops and dilapidated bathhouses when the governor came to towns" (Dio Chrysostom 40.9; translation in Gleason 2006, 231).

42 Summary in Burrell 2004, 355-356.

43 Bliege Bird and Smith 2005, 235.

44 Millar 1993.

45 Duncan-Jones 1990, 177 gives the cost of a single medium-sized temple in North Africa in the second century $\mathrm{AD}$ as 60,000-70,000 sesterces, which equates, using figures given by Zuiderhoek 2009, 25, to the annual subsistence for some 500 people. 
Focusing on the individual level first, interpretation is mixed. On one hand, Zuiderhoek (2005, 2009) emphasizes for Roman Asia Minor, first, that cities are being outfitted not solely through individual beneficence, but also, and possibly even primarily, through the deployment of city resources coming from indirect taxes and liturgies. Second, using estimates of productivity and income, he argues that at most, on average, $5 \%$ or less of the annual aggregate elite income was devoted to public building. ${ }^{46}$ But, it must be emphasized that Zuiderhoek is here talking about averages and aggregates. As Neiman (1997) emphasizes, it is in actual competitive matchups where signal quality is assessed; one need be perceptibly better then one's closest rival to win the contest at hand.

On the other hand, it is clear that only the very wealthy could afford to make benefactions of entire buildings. Certainly, such benefactions seem to be very rare $^{47}$ and they often were made by the same individual or family. This pattern is seen in Marest-Caffey's (2008) work on benefactions for late Hellenistic Anatolia, Duncan-Jones' (1990) comparative analysis of Thugga and Thamugadi in Roman North Africa, and Zuiderhoek's $(2005,2009)$ sample of 44 inscriptions from his larger database, focusing on second-through-third-century Imperial western Asia Minor (primarily Lycia).

For Asia Minor during the high Imperial period, Zuiderhoek ${ }^{48}$ reports that, excluding gifts of entire buildings, $60 \%$ of the public benefactions attested to by inscription in his database are "small," 1000 denarii or less. By Zuiderhoek's reckoning $(2005,2009)$, 1000 denarii represents $80 \%$ of the annual income that would come from rent on land valued at 25,000 denarii, the minimum wealth requirement for a citizen seeking a position as a councilor. Thus, even these "small" benefactions are being made by a class of families we might call almost wealthy or peri-wealthy.

All the same, even with this information we do not have contextual information to know how wealthy the peri-wealthy are and if in fact a particular benefaction constitutes a real cost to them and their families. It would be useful, for example, to have a complete distribution of benefaction sums and compare this distribution with distributions of wealth as attested to by mortuary or domestic materials. If our signaling hypothesis holds water, then we would expect to see an exaggerated mode of benefactions for the almost wealthy and peri-wealthy, those striving to establish their status in a dynamic social structure.

\footnotetext{
46 Zuiderhoek 2009, 35 .

47 Migeotte 1997.

$48 \quad 2009,29$.
} 
Other textual evidence exists, however. For Classical Greece ${ }^{49}$ we know strategies existed whereby wealthy individuals would attempt to shift their imposed liturgies to another and the same is documented for the Roman period. ${ }^{50}$ For the Imperial period, we know that civic obligations might ruin a family and had to be managed very carefully, ${ }^{51}$ suggesting that real costs are being incurred by at least some of the wealthy. And, finally, sumptuary laws were enacted during the period $100 \mathrm{BC}$ to $\mathrm{AD} 50$ to rein in the incredible displays of wealth being made by individuals. One interpretation of these laws is that they provided cover so that aristocrats could avoid bankruptcy. ${ }^{52}$

On balance, then, it seems as though public buildings and the adornments and embellishments also donated, with benefactors' names advertised, do indeed represent a costly display by individuals and families. But, moving now to the group level, does the public architecture of the polis represent a costly group signal? Echoing Roscoe (2009) regarding New Guinea villages at contact, failure to compose a strong group signal that reflects effective collective action is to invite disaster within the hyper-competitive arenas of either Hellenistic peer polities ${ }^{53}$ or the Imperial world in which first citizens, first cities, and first provinces were recognized and rewarded. ${ }^{54}$

Textual evidence shows that cities could to be accused of engaging in building viewed as too costly. Thus, that too much wealth was being devoted to the construction of a monumental cityscape became of concern during the high Imperial period. "[Public buildings] had to be restricted, in the interests of preventing wasteful expenditure and unhealthy inter-city rivalry." ${ }^{55}$ If city building plans were deemed too grand, Rome might send a corrector or auditor to reorganize city finances. ${ }^{56}$

\section{Citizen and City Costly Signaling}

In the preceding paragraphs, I have attempted to make the case that the public architecture of the polis can be viewed as the costly signals of individuals

\footnotetext{
49 Carmichael 1997; Veyne 1976.

50 Gleason 2006; Price 1984.

51 Price 1984; Veyne 1976; Zuiderhoek 2009.

52 Parkins 1997, 90-91; Zanker 1990, 25.

53 Ma 2000, 2003.

54 For "neokoroi" see Burrell 2004; Price 1984.

55 Mitchell 1993, 81.

$5^{6}$ Burrell 2004; Gleason 2006, 246.
} 
upon which are piggybacked the costly signal being constructed by city. The individual signals allow for decisions about whom to admit to the council or to hold city offices (at least for males), with decisions made at first by the demos (in Hellenistic times) and then later by the oligarchy (in Imperial times and possibly earlier). Those office holders often had the multi-faceted responsibility for negotiating the place of the city (and its citizens) in the complex and competitive world of the eastern Mediterranean. The cityscape itself - the sets of buildings, their location, and their ornateness - provides an overall index of collective action. Moreover, the manifestations of city institutions in the form of monumental stone within the cityscape sends a signal about city values and power structures to residents and visitors, citizens and non-citizens, that might be effective in repelling foes and recruiting new members.

From the above, we might expect material signals to become especially important as city size increases and as city populations include more foreigners who transact social matters using more than one language. Such signals should also be important when stressful conditions prevail, creating opportunities for signalers, both individuals and groups, to display both their prosocial orientation and their effectiveness. The Hellenistic period for western Anatolia and early Imperial Asia Minor saw exactly these conditions.

\section{Citizen and City Signaling in Late Hellenistic Anatolia}

The Hellenistic period of the eastern Mediterranean was, as Ma notes, the "age of the city-states [or] poleis ... of kings ... and of elephants, gigantic warships, imperial processions, and stupendous feasting and drinking." ${ }^{n 7}$ During this time Greek city culture expanded both within the greater Mediterranean basin and also to the east and beyond through colonization and other means. Whereas the hundreds of colonies established during the heyday of early Greek colonization $\left(75^{\circ}-55^{\circ} \mathrm{BC}\right)$ had been confined to coastal areas around the Mediterranean and Black Sea, during the Hellenistic period new cities (perhaps as many as 150) appeared in the wake of Alexander throughout Anatolia, Syria, Palestine, and Mesopotamia. ${ }^{58}$ These cities likely represented previously existing cities that now included a Greek population, a new Greek name and, critically, Greek civic institutions. ${ }^{59}$ Simultaneously, some non-Greek cities in Anatolia, e.g., Alabanda, came to adopt Greek political language and civic apparatus. ${ }^{60}$

\footnotetext{
57 Ma 2003, 13.

$5^{8} \quad$ Billows 2003; Cohen 1995.

59 Billows 2003, 198.

6o Ma 2003, 25-26, 38 .
} 
During the early Hellenistic period (fourth and third centuries BC), the location of western Anatolia, at distance from the centers from which the various Successors to Alexander operated, meant that cities, depending on strategic location and resources, variously received the welcome and unwelcome attention of multiple vying Successor kings. ${ }^{61}$ Thus, cities here were inadvertent participants in the big wars of the Successors for tribute but also inveterate contestants in the small wars fought by the cities themselves for territory. ${ }^{62}$

During the later Hellenistic period, as the influence of Alexander's Successors waned, piracy and predation by land-based brigands increased. At this time, then, captured citizens might be sold into slavery if not ransomed by kin or by civic benefactors. ${ }^{63}$ A Roman presence in the area was initially limited but, for several interrelated reasons, gradually increased during this time. In exchange for their support, Mithridates vi of Pontus (echoing earlier tyrants) offered Anatolian Greek cities autonomy and escape from Roman subordination. To deal with piracy as well as Mithridates and the usurper Aristonicus, who attempted to hold the Attalid bequest to Rome, Rome increased its involvement in the area. ${ }^{64}$ Subsequently, the civil wars of the late Roman Republic spilled over into western Anatolia, with Anatolian cities forced to garrison and support Roman troops.

Over the course of the Hellenistic period, then, the cities of western Anatolia endured stresses and strains that varied by location, intensity, and the degree to which relief could be sought via an embassy. While interpretation of population levels is mixed, ${ }^{65}$ on balance it seems reasonable to postulate an increase in population for western Anatolian cities, in spite of these stresses. Assuming Classic era Anatolian cities were similar in size to those in Greece, cities may have been the residence for 1,000-2,000 (more rarely 5,000-10,000) inhabitants. ${ }^{66}$ In the later Hellenistic era, population is estimated at 2,60o3,000 (e.g., Priene) with some cities (Ephesus, Smyrna) approaching or exceeding $100,000 .{ }^{67}$ Individual wealth also increased. ${ }^{68}$ Finally, we see in Hellenistic times an increase in the proportion of foreigners-Greek and non-Greek,

\footnotetext{
61 Gauthier 1993; Ma 2003; Millar 1993.

62 Chaniotis 2005; Ma 2000.

63 De Souza 2000; Gabrielsen 2003.

64 Sherwin-White 1977 .

65 See Reger 2003 334-335 for summary.

66 Hansen 2000.

67 Billows 2003, 201.

68 Rostovtzeff 1941. And, extending Zuiderhoek's (2009 53-6o) neo-Ricardian analysis into the late Hellenistic era, limited agricultural land along with an increasing population
} 


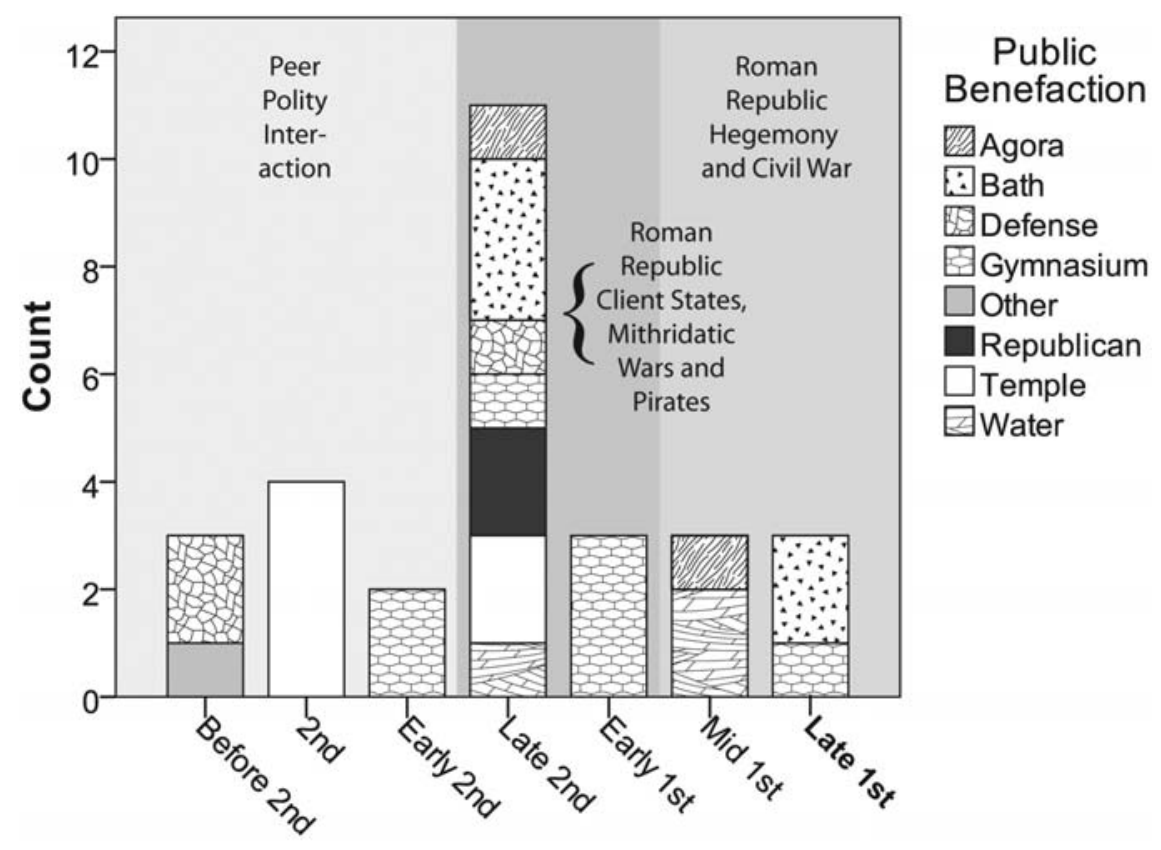

Time Period (Century BC)

FIgURE 3.1 Thirty Accounts of Aedilitian Public Benefactions Compiled by Marest-Caffey (2008) for Late Hellenistic Anatolia. Note that time periods are unequal and benefaction frequencies have not been standardized by number of years in each time period.

transient and resident, later including Romans-in Greek cities. ${ }^{69}$ All of these aspects are important because they are precisely the conditions in which an expensive multi-lingual material signal, such as a monumental public building, might be most effective in conveying individual prosocial talent and group competence.

The records of building benefactions compiled by Marest-Caffey (2008) for western Anatolian cities allow for a preliminary examination of this thesis. ${ }^{70}$

meant that land, owned by the wealthy, became even more valuable, allowing the wealthy even more surplus to be used for display purposes.

69 Chamoux 2003, 197-200; Mitchell 2000.

70 Marest-Caffey's thesis explores the content and context for epigraphic inscriptions mentioning building benefactions, usually portions of buildings, by very wealthy members of the cities, including women, of western Anatolia. She works with inscriptions describing thirty benefactions that range in age from before the second century $\mathrm{BC}$ until just prior to the Roman Imperial period. 
This evaluation is limited by the fact that the inscriptions are drawn from a restricted time period (especially the middle to late Hellenistic period) and the total number is quite small. Nevertheless, Figure 3.1 shows trends consistent with the expectations given above. That is, during the late second century $\mathrm{BC}$, precisely when cities are in need of citizens to lead embassies to other cities or to the Roman Senate to argue for leniency, civic benefactions involving public buildings peak. For example, Marest-Caffey (2008) reviews the record of the career of Menippos of Kolophon. He engaged in many acts of civic beneficence, included providing money for the construction of the doorframe for the pronaos of the temple to Apollo (Claros 64-65, col. II, ll. 24-33) and paying for the quartering of the governor Quintus Mucius Scaevola and his troops at Kolophon (Claros 65, col. II, ll. 42-46). Of note here, Menippos was sent to the Roman Senate on five occasions to speak on behalf of Kolophon. And, the decrees also indicate that benefactors like Menippos often held some sort of city office, sometimes quite prestigious. For example, Menippos was twice elected as strategos (general; Claros 64, col. II, ll. 7-18), held the office of prytanis (the eponymous office of Kolophon) and served as agonothetēs (superintendent of sacred games; Claros 65, col. II, ll. 33-44).

Marest-Caffey's compilation also allows for analysis of architectural signals with multiple audiences. ${ }^{71}$ That is, we can dimly see the political or social messages being conveyed by the erectors of particular architecture, as exemplified by Hansen and Fischer-Hansen's (1994) interpretation of the changes seen in monumental architecture over time. As Figure 3.1 shows, fortifications are mentioned in honorific decrees early on, when intercity warfare and negotiation were elevated; gymnasia and baths later on, as new citizens and Roman sponsors were recruited. Temples, critical to the definition of a unique city identity, feature prominently during the second century and the late second century. Bouleuterion and prytaneion construction and repair, i.e., work on public buildings associated with increasingly oligarchic but nevertheless republican institutions of the council and magistracies, was acknowledged in the later second century, as various pressures (indirect Roman Republican presence and resistance to that presence, piracy) were felt by the cities.

In sum, this latter time period was especially stressful for cities and, thus, opportunities for acts of solidaristic civic benefaction abounded. Second, there existed various stable targets for embassies from the cities to seek relief, including other cities and the Roman Senate. Given this situation, a means for identifying (and rewarding) individuals with diplomatic skills, charisma, a prosocial 
orientation and other resources that might lead to a successful mission was critical; the behaviors usually glossed as civic benefactions, and here referred to as social signals, served in this capacity. Third, a combination of economic factors and simple scalar factors contributed to inter-individual competition. Wealth appears to have increased as did city population (in spite of plagues and warfare). But given that polis institutions had preset restricted sizes (e.g., council size of 100), a mechanism for sorting out the crowd at the gate, via culturally condoned social signaling, became inevitable. Veyne's "rise of the notables," who deployed public benefactions enhancing self and city, should not be seen as an exceptional event, but, rather an expectable trend.

\section{Citizen and City Signaling in Roman Asia Minor}

Troops, wealthy patrons, and publicans of the Roman Republic were active in portions of western Anatolia beginning about $200 \mathrm{BC}$. The Roman province of Asia was organized in 133 BC by Manius Aquillius and subsequently, but especially just before the Imperial period, Roman involvement in the area accelerated. Then, population centers of indigenous peoples along with resident Greeks and Romans (especially in interior Asia Minor) were deliberately organized into communities by agents of Rome. At this time, a city government based on a modified Greek model was installed. Towns and other units were formally designated and made subordinate to nearby cities. ${ }^{72}$

In general, population levels increased for the circum-Mediterranean from the Late Republic into the early and High Imperial times ${ }^{73}$ and certainly population reorganization, through top-down and local bottom-up forces, ${ }^{74}$ occurred. For Greek and newly organized Greco-Roman cities in Asia Minor, population estimates range from 180,000 for major cities like Pergamum (western Asia Minor) to 25,000 for few large urban centers, to 5,000-15,000 for most communities. ${ }^{75}$

In such cities, the local indigenous language was spoken but Greek was used in civic discourse, performance, and even by agents of Rome in their communications with the city. ${ }^{76}$ In other words, not only are multiple kin groups co-residing in these communities, but so too are speakers of multiple language groups. ${ }^{77}$

72 Mitchell 1993, 176-179.

73 See Zuiderhoek 2009, 42-43 for summary.

74 See discussion by Alcock 1993 .

75 Mitchell 1993, 243-244.

76 Gleason 2006, 229 .

77 The definition of "individual" should also likely be adjusted. In Classical times, the "effec- 
The populace of Asia Minor benefited from its incorporation into the empire in several ways. Pax Romana, an expanding network of roads, and a consistently applied legal system led to a general increase in circulating wealth even as wealth disparities were magnified. Mentioned above, Zuiderhoek ${ }^{78}$ highlights the confluence of increasing population and limited agricultural land, leading to the relative scarcity and, hence, increased value of the latter. Thus, the holders of agricultural land became relatively wealthier over this interval.

For the Late Hellenistic period, poor decisions by cities, for example, to support Aristonicus or Mithridates, led to significant sanctions imposed by the victorious Romans. Also, piracy and brigandage meant that citizens were exposed to real personal threats. While actual peril to citizens and cities of Asia Minor diminished in the Imperial period, this does not mean that competition ceased. Rather, it assumed new forms with different dynamics.

At the individual level, the competition for reputation that occurred among elite individuals and families of Asia Minor soared to new heights. ${ }^{79}$ Zuiderhoek's (2009) recent analysis of civic benefactions testified to in inscriptions for Asia Minor shows a major peak for the second century AD falling off into the third and fourth centuries. Zuiderhoek reviews and critiques the various reasons given for this increase, and he finds them all wanting. He argues, instead, that these acts of civic benefaction, which, importantly, are acknowledged in stone by city institutions, are acts of legitimation both on the part of the benefactor elite citizen and the citizen recipient. To maintain the stability and internal cohesion of the city when new levels of wealth inequality had developed, to mask the decline in the power of the democratic assemblies (by which cities still presented themselves to the world, as seen in inscriptions) and to naturalize the ongoing ideological transition from that of Classical isonomia (equality of rights for all) to the extant hierarchical order, this mechanism was critical and, hence, prolifically enacted, he argues. ${ }^{80}$

But Zuiderhoek ${ }^{81}$ also offers another explanation, to which I have alluded to above. That is, these acts of civic benefaction may also be seen as signals to the members of the new, exclusive, and dynamic bouleutic order. They are

tive individual" was a citizen of a specific polis. Citizenship was limited to males. By Late Hellenistic times, females, foreigners, and freed slaves, in addition to male citizens, are operating as "effective individuals," (Pomeroy 1997) further exacerbating the scalar effects described herein.

$78 \quad 2009,53-60$.

79 Gleason 2006; Price 1984; Veyne 1976; Zuiderhoek 2009.

8o See also Gleason 2006.

$812009,133$. 
demonstrations of the prosocial competency of individuals (and their families) to operate in this order. ${ }^{82}$

Zuiderhoek offers proximate explanations. Ultimately, this inter-individual competition may have been driven by the same factors mentioned for the Hellenistic case: opportunity for signaling, simple scalar issues, and available wealth. Envoys dispatched by the cities to the Governor or to Rome were instrumental in securing privileges as well as the commitment from the emperor to provide the splendid set of public buildings to which contemporary writers frequently refer. ${ }^{83}$ According to my argument, costly signaling, i.e., civic benefactions, by individuals, would help identify those individuals best able to take the city's case to the Governor. In terms of scale, take two cities-one small, one large, both with the same civic institutions - the opportunities for individual access to those institutions will be more limited in the case of the city with a larger body of citizens. Newly available wealth exacerbated this situation, leading to magnificent ostentatious displays in monumental architecture.

For the newly founded and refounded cities of Lycia, however, the story may be different. Given the complex history of Lycia, especially interior Lycia, ${ }^{84}$ the Classic Greek ideology of isonomia may have been less significant. In addition to the factors mentioned above, communicating their status, i.e., indexical signaling, and their commitment to the new Roman order, i.e., canonical signaling, may have been even more important to the members of the new urban elite.

On the level of cities operating in competitive provinces, indexical signaling by city institutions seems evident. By Imperial times, a city was defined in terms of civic buildings (rather than the autonomy valued by earlier Classic and even Hellenistic cities; Mitchell 1993, 80). Cities made proposals to the emperor to initiate a cult in his name and/or build a temple to him. Funds for the temple and culture came from the emperor, the city, the province, or local wealthy individuals and "provincial cities all but bankrupted themselves (and sometimes did) in competition with each other." ${ }^{85}$ Imperial cult temples became

$82 \quad$ Here it would be useful to be able to better resolve sequence and also follow the careers of the "also rans." Are public benefactions being made especially in the early portion of the careers of the notables, that is, before they have been elected to the boule? Inscriptions acknowledge successful transactions between individual and city institutions; we are ignorant about those who attempted to join the ranks of the bouleutic order but were not successful.

83 Burrell 2004, 331-334.

84 Colvin 2004; Keen 1998; Ten Cate 1965.

85 Ratté 2001123. 
the sites of cult festivities attended by representatives from cities throughout the province and also were where honorific statues of local dignitaries were put up. ${ }^{86}$ Cities making (and being granted) such requests also put themselves on the map in terms of being considered for the site of an assize, or to the claim of First City, for which competition was fierce, and Rome was adept at playing cities off against each other. ${ }^{87}$

But canonical signaling, that the city is part of the new Imperial world order, is also evident. Notes Millar: "It is not too much to say that the public self-expression of the 'Greek-city' in the Empire embodied at every level an explicit recognition of the distant presence of the Emperor."88 And, writes Ratté:

At Aphrodisias, as elsewhere, these monuments served paradoxically both to advertise through status and inscriptions the generosity of their individual donors, and to clothe the city in that homogenous 'international style', instantly recognizable at archaeological sites throughout Turkey and to a lesser degree throughout the eastern Mediterranean world. ${ }^{89}$

That the materiality of the citizen and city signal was important, especially in the earlier part of the period, ${ }^{90}$ is supported by epigraphic data on civic benefactions compiled by Zuiderhoek. Zuiderhoek reports that for 399 inscriptions from Imperial Asia Minor, $58 \%$ of these acknowledge benefactors for contributing to public buildings, while distributions of food and oil are named in $17 \%$ and $13 \%$ refer to games and festivals. ${ }^{91}$ ("Miscellaneous" comprises the remaining $12 \%$ ). He offers a longitudinal depiction for each of these classes of benefactions, ${ }^{92}$ which, using figures in his Figure $5.1,{ }^{93}$ I have recalculated to present in terms of frequencies rather than percentages. Figure 3.2 shows that public building benefactions always exceed other forms of benefaction in Asia Minor. Benefactions in general are lower in the first and third centuries, peaking in the second. In the first century public buildings comprise the bulk of

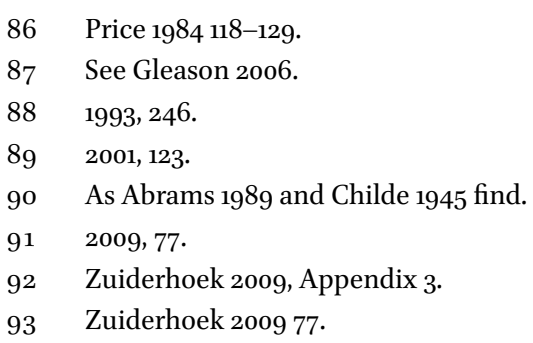




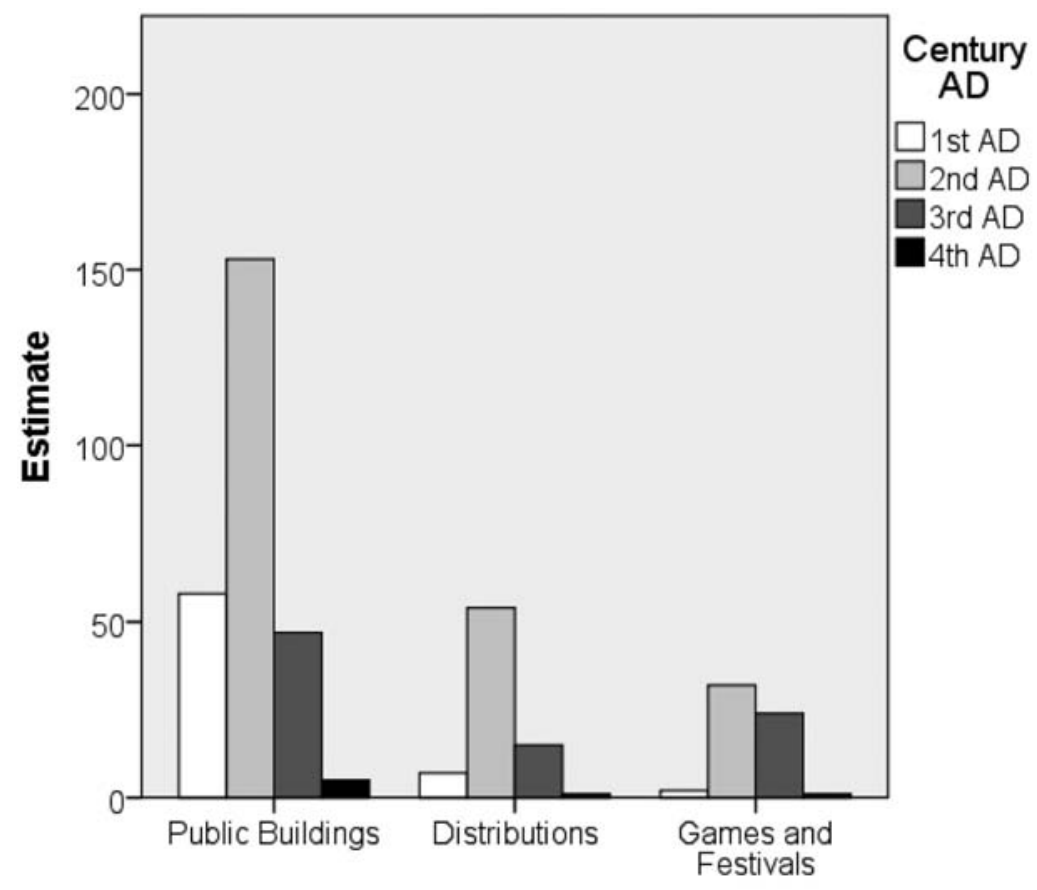

\section{Public Benefaction}

FIGURE 3.2 Estimated Public Benefactions Documented in 399 Inscriptions from Imperial Asia Minor (Zuiderhoek 2009 Appendix 3) as calculated using Figures given in Zuiderhoek 20og, Figure 5.1.

the benefactions, $85 \%$, while in the second and third centuries other forms of benefactions are acknowledged; public building benefactions amount to $65 \%$ in the second and $55 \%$ in the third centuries. Thus, while from the time of Septimius Severus (AD 193) to the mid-third century there was a major expansion of inter-city agonistic competition (i.e., competitions in sports, music, and theatre embedded within the framework of religious festivals), ${ }^{94}$ civic benefactions of public buildings still remained high.

Some of that high frequency of public building civic benefaction seen in the Imperial period, then, is owed, almost mechanistically, to the formation and outfitting of new cities. Given the cosmopolitan and likely multi-lingual nature of these communities, we would expect public architecture to feature prominently in signaling both community identity and also allegiance towards the 
emperor, following on observations by Childe (1945), Abrams (1989), and Trigger (1990) on the effectiveness of architecture as a trans-lingual communication device. Analysis of epigraphic evidence ${ }^{95}$ at the macro-scale, and more microscale analyses, like that described by van Nijf (2011), are well poised to explore this matter further.

\section{Signaling and Polis Viability}

Signaling theory may help us to appreciate differential city endurance and growth as well as the post-disaster fate of a polis. That is, do poleis for which we can demonstrate early and/or continuing investments in public architecture (signaling coherent and effective collective action) persist better than those poleis without such architecture? Do cities rich in dynamic and wellmaintained public architecture grow faster than their sister cities?

Cities in Anatolia and Asia Minor were subject to many different kinds of assaults, both internal and external. During Hellenistic times, for example, cities were often divided by factionalism, with some factions supporting Aristonicus or Mithridates in their local efforts to assert claims to territory and tribute and other factions supporting the Roman responders. ${ }^{96}$ In Imperial times, cities that did not maintain harmonious social relations across lines of privilege courted Roman scrutiny and the presence of troops; ${ }^{97}$ the strife ensuing when Paul spoke in Ephesus was to be avoided. In addition to the threat of exorbitant tribute requirements or predation by publicans and pirates, external threats included earthquakes, small and large, which rocked this part of the world on an almost routine basis, ${ }^{98}$ as well plague, crop failure, and pests.

Some cities survived these disasters, others did not. ${ }^{99}$ Cities were enmeshed in a network of social and kin relations. ${ }^{100}$ On what basis did kin and friends assist threatened cities? Did assistance come no matter what or was it preferentially lent to those groups that had demonstrated prosocial behaviors? Was survivorship or persistence correlated with the presence or number of prosocial actors, i.e., civic benefactors, as manifested in donations of public architecture to the city? When Rhodes was devastated by earthquakes in $228 / 227 \mathrm{BC}$, help

\footnotetext{
95 E.g. Zuiderhoek 2009.

96 Marest-Caffey 2008.

97 Gleason 2006; van Nijf 1997.

98 Guidoboni et al. 1994.

99 And some cities were re-founded elsewhere following disasters, as reviewed by Mackil 2004.

$100 \quad$ Ma 2003; Mackil 2004; Rigsby 1996.
} 
was quick to come from several monarchs, ${ }^{101}$ and here the strategic situation of Rhodes was likely instrumental. Similarly, when Ephesus, now the seat of the Roman proconsul, was struck in AD 23, its status likely contributed to its rebuilding. ${ }^{102}$ For other smaller cities, such as Cnidus ${ }^{103}$ and Priene, ${ }^{104}$ their post-earthquake reconstruction histories may comment on this notion. The rich corpus of textual, archaeological, and numismatic evidence for western Anatolia and Asia Minor almost uniquely allows us to entertain these questions of differential persistence over the medium term.

\section{Concluding Remarks}

Signaling theory stipulates that particular signals convey information closely linked to otherwise difficult-to-assess capabilities of individual and groups. At the individual level, the construction of an acknowledged public building visibly communicates something important about the capabilities of the individual: that they possess the ability to negotiate a complex situation, i.e., the nature and size (and location of a building or timing of a festival) of the gift to the citizens; that they have received an elite education received by many of the benefactors, ${ }^{105}$ especially from the later Hellenistic period onward. Presumably, the social network available to such individuals is also critical. ${ }^{106}$ Presumably, some elites were more interested in and excelled at complex negotiations than others. And, presumably, these same diplomatic talents were useful when dealing with a neighboring city or a Roman governor, although this question should be examined empirically.

At the community level, the effectiveness of city institutions and the prosocial orientation of its citizens is indexed by its public buildings. That is, the public architecture of the city materially represents the successful negotiations of various polis institutions - the council, the assembly, and, in Imperial times, collegia ${ }^{107}$ — as well as the presence of wealthy individuals and families. And, even if euergetism was responsible for a small portion of public building, that the polis is able to harness resources from multiple disparate sources,

\footnotetext{
101 Cohen 1995, 25.

102 Scherrer 2001.

103 Altunel et al. 2003.

104 Altunel 1998.

105 Watts 2006.

106 Zuiderhoek 2008.

107 van Nijf 1997.
} 
including subscriptions, is further testament to its proficiency in collective action. Presumably, cities with dysfunctional institutions or more selfish citizens were more poorly outfitted than cities with institutional accord. Again, this is an empirical question that the record from Anatolia/Asia Minor is well suited to address.

The cities of western Anatolia and Asia Minor were the fora within which complex social, economic, and political transactions and negotiations occurred. Citizens and cities were not merely "fighting over a shadow." Rather, these "fights" had consequences for individual citizens and their progeny and also for individual cities. Here, I have focused on one class of these transactions, public benefactions and public architecture, and, deploying signaling theory, have characterized them as social signals. Moreover, I have emphasized the materiality of signals, arguing that the city, more specifically, public buildings or the city fabric, was also the medium (although, likely not the sole medium) employed in these transactions. This approach lays a foundation for future work exploring the differential success of citizens and cities.

\section{Acknowledgements}

I thank the organizers of the conference Urban Dreams, Urban Realities for assembling a splendid feast. I thank my colleagues from the Rough Cilicia Archaeology project, Nicholas Rauh, Matthew Dillon, Michael Hoff and Rhys Townsend, for my initial introduction to civic benefactions. Carolyn Heitman, Michael Hoff, Fraser Neiman, and Paul Roscoe provided useful suggestions for improving this chapter, for which I am grateful. Finally, I make heavy use of the work of others here, especially Laure Marest-Caffey and Arjan Zuiderhoek. I thank these authors for their fine efforts.

\section{Bibliography}

Abrams, Elliot. 1989. "Architecture and Energy: An Evolutionary Perspective," in Archaeological Method and Theory Vol. 1, ed. Michael B. Schiffer. 47-87. Tucson Az: University of Arizona Press.

Alcock, S.E. 1993. Graecia Capta: The Landscapes of Roman Greece. Cambridge: Cambridge University Press.

- 2002. Archaeologies of the Greek Past: Landscape, Monuments, and Memories. Cambridge: Cambridge University Press.

Altunel, Erhan 1998. "Evidence for damaging historical earthquakes at Priene, Western

Turkey." Turkish Journal of Earth Sciences 7: 25-35. 
_ I Iain S. Stewart, Aykut Barka, and Luigi Piccardi. 2003. "Earthquake faulting at ancient Cnidus, sw Turkey." Turkish Journal of Earth Sciences 12: 137-151.

Billows, Richard. 2003. "Cities," in A Companion to the Hellenistic World, ed. Andrew Erskine, 196-216. Malden MA: Blackwell Publishing.

Blanton, Richard. 1989. "Continuity and Change in Public Architecture: Periods I through v of the Valley of Oaxaca, Mexico", in Monte Alban's Hinterland Part II: Settlement Patterns in Tlacolula, Etla, and Ocatlan, Valley of Oaxaca, Mexico, Vol.. . eds. S. Kowalewski, G. Feinman, R. Blanton, L. Finsten, and L. Nichols. Ann Arbor, MI: Museum of Anthropology, University of Michigan. 409-447.

- 1994. Houses and Households: A Comparative Study. New York: Plenum Press.

Bliege Bird, Rebecca, and Eric Alden Smith. 2005. "Signaling Theory, Strategic Interaction and Symbolic Capital." Current Anthropology 46 (2): 221-248.

Boone, James L. 1998. "The Evolution of Magnanimity: When Is It Better to Give Than to Receive?" Human Nature 9 (1): 1-21.

. 2000. "Social Power, Status, and Lineage Survival", in Hierarchies in Action: Cui Bono? ed. M.W. Diehl. Carbondale IL: Southern Illinois University Press. 84-110.

Borowicz, James J. 2002. Images of Power and the Power of Images: Iconography of Stelae as an Indicator of Socio-Political Events in the Early Classic Maya Lowlands. Buffalo: State University of New York at Buffalo.

Bourdieu, Pierre. 1986. "The Forms of Capital", in Handbook of Theory of Research for the Sociology of Education, ed. J.E. Richardson. Westport ст: Greenwood Press. 46-58.

Bowles, Samuel, and Herbert Gintis. 2003. "Origins of Human Cooperation", in Genetic and Cultural Evolution of Cooperation, ed. Peter Hammerstein. Cambridge MA: MIT Press. 401-428.

Boyd, Robert, and Peter J. Richerson. 1992. "Punishment Allows the Evolution of Cooperation (or Anything Else) in Sizeable Groups." Ethology and Sociobiology 13: 171-195.

Burrell, Barbara. 2004. Neokoroi: Greek Cities and Roman Emperors. Cincinnati Classic Studies New Series Vol. 9. Leiden: Brill.

Camp, John McK. 2000. "Walls and the Polis," in Polis and Politics: Studies in Ancient Greek History, eds. Pernille Flensted-Jensen, Thomas Heine Nielsen, and Lene Rubinstein. Copenhagen: Museum Tusculanum Press, University of Copenhagen. 41-58.

Carmichael, Calum M. 1997. "Public Munificence for Private Benefit in Classical Athens." Economic Inquiry 35 (3): 261-270.

Chamoux, François. 2003. Hellenistic Civilization. Malden MA: Blackwell.

Chaniotis, Angelos. 2005. War in the Hellenistic World: A Social and Cultural History. Malden MA: Blackwell.

Childe, V.G. 1945. "Directional Changes in Funerary Practices during 50,00o Years." Man 45: 13-19.

Cohen, Getzel M. 1995. The Hellenistic Settlements in Europe, the Islands, and Asia Minor. Berkeley CA: University of California Press. 
Colvin, Stephen. 2004. "Names in Hellenistic and Roman Lycia", in The Greco-Roman East: Politics, Culture, Society, ed. Stephen Colvin. Yale Classical Studies. Cambridge: Cambridge University Press. 31:44-84.

Darwin, Charles. 1922. The Descent of Man, and Selection in Relation to Sex. 2nd ed. London: John Murray.

Dmitriev, Sviatoslav. 2005. City Government in Hellenistic and Roman Asia Minor. Oxford: Oxford University Press.

Duncan-Jones, Richard. 1990. Structure and Scale in the Roman Economy. Cambridge: Cambridge University Press.

van Dyke, Ruth M., and Susan E. Alcock. 2003. "Archaeologies of Memory: An Introduction," in Archaeologies of Memory, ed. Ruth M. van Dyke and Susan E. Alcock. Malden MA: Blackwell. 1-13.

Fagan, G.G. 2002. Bathing in Public in the Roman World. Ann Arbor MI: University of Michigan Press.

Ferrary, Jean-Louis. 1997. “The Hellenistic World and Roman Political Patronage”, in Hellenistic Constructs: Essays in Culture, History, and Historiography, eds. Paul Cartledge, Peter Garnsey, and Erich Gruen. Berkeley CA: University of California Press. 105-119.

Gabrielsen, Vincent. 2003. "Piracy and the Slave-Trade", in A Companion to the Hellenistic World, ed. Andrew Erskine. Malden MA: Blackwell. 389-404.

Gauthier, Philippe. 1985. Les Cités Grecques et leurs Beinfaiteurs (IVe-Ier Siecle avant J.-C.). Contribution à l'Histoire des Institutions. Bulletin de Correspondance Hellénique, Supplément XıI. Athens: École Française d'Athènes.

. 1993. "Les Cités Hellénistiques," in The Ancient Greek City-State, ed. Mogens Herman Hansen, Historisk-filosofiske Meddelelser. Copenhagen: Det Kongelige Danske VidenskabernesSelskab. 67:211-231.

Gintis, Herbert, Eric Alden Smith, and Samuel Bowles. 2001. "Costly Signaling and Cooperation." Journal of Theoretical Biology 213 (1): 103-119.

Glatz, Claudia, and Aimée M. Plourde. 2011. "Landscape Monuments and Political Competition in Late Bronze Age Anatolia: An Investigation of Costly Signaling Theory." Bulletin of the American Schools of Oriental Research 361: 33-66.

Gleason, Maud. 20o6. "Greek Cities under Roman Rule", in A Companion to the Roman Empire, ed. David S. Potter. Malden MA: Blackwell. 228-249.

Grafen, Alan. 1990. "Biological Signals as Handicaps.” Journal of Theoretical Biology 144: 517-546.

Guidoboni, E., A. Comastri, and G. Traina. 1994. Catalogue of Ancient Earthquakes in the Mediterranean Area up to the 1oth Century. Vol. 1. Rome: Instituo Nazionale di Geofisica.

Hansen, Mogens Herman. 200o. "The Hellenic Polis," in A Comparative Study of Thirty City-State Cultures: An Investigation, ed. Mogens Herman Hansen. Copenhagen: Kongelige Danske Videnskabernes Selskab. 141-188. 
and Tobias Fischer-Hansen. 1994. "Monumental Political Architecture in Archaic and Classical Greek Poleis. Evidence and Historical Significance", in From Political Architecture to Stephanus Byzantius: Sources for the Ancient Greek Polis, ed. David Whitehead. Papers from the Copenhagen Polis Centre 1. Stuttgart: Franz Steiner. 2390.

Henrich, J. 2006. "Cooperation, Punishment, and the Evolution of Human Institutions." Science 312: 60-61.

Higham, James P. 2014. “How Does Honest Costly Signaling Work?" Behavioral Ecology 25 (1): 8-11.

Keen, Antony G. 1998. Dynastic Lycia: A Political History of the Lycians \& Their Relations with Foreign Powers, c. 545-362 Bc. Leiden: Brill.

Ma, John. 200o. "Fighting Poleis of the Hellenistic World", in War and Violence in Ancient Greece, ed. Hans van Wees. London: The Classical Press of Wales. 337-376.

- 2003. "Peer Polity Interaction in the Hellenistic Age." Past and Present 180: 9-39.

Mackil, E. 2004. "Wandering cities: alternatives to catastrophe in the Greek polis." American Journal of Archaeology: 493-516.

Marcus, Joyce. 2003. "Monumentality in archaic states: Lessons learned from large-scale excavations of the past", in Theory and Practice in Mediterranean Archaeology: Old World and New World Perspectives, eds. J.K. Papadopoulos and R.M. Leventhal. Los Angeles CA: UCLA Cotsen Institute of Archaeology. 115-134.

Marest-Caffey, Laure. 2008. Public Works in the City-States of Anatolia during the Late Hellenistic Period: The Role of Euergetism and Citizens' Initiatives. M.A., California State University Northridge.

McGuire, Kelly, and William Hildebrandt. 2005. "Re-thinking Great Basin Foragers: Prestige Hunting and Costly Signaling during the Middle Archaic Period." American Antiquity 70 (4): 695-712.

Migeotte, Léopold. 1992. Les Souscriptions Publiques dans les Cités Grecques. Genève: Droz.

- 1995. "Finances et constructions publiques," in Stadtbild und Bürgerbild im Hellenismus, ed. Michael Wörrle and Paul Zanker. München: Beck. 79-85.

—. 1997. "L'Évergétisme des citoyens aux périodes classique et hellénistique", in Actes du xe Congrès International de'Épigraphie Grecque et Latine, eds. Christol. Michel and Olivier Masson. Paris: Publications de la Sorbonne. 183-196.

Millar, Fergus. 1993. "The Greek City in the Roman Period", in The Ancient Greek CityState, ed. Mogens Herman Hansen, Historisk-filosofiske Meddelelser 67:232-26o. Copenhagen: Det Kongelige Danske VidenskabernesSelskab.

Mitchell, Stephen. 1993. Anatolia: Land, Men, and Gods in Asia Minor. Oxford: Clarendon Press.

Minor", in Ethnicity and Culture in Late Antiquity, eds. Stephen Mitchell and Geoffrey Greatrex. London: Duckworth and the Classical Press of Wales. 117-150. 
Neiman, Fraser D. 1997. "Conspicuous Consumption as Wasteful Advertizing: A Darwinian Perspective on Spatial Patterns in Classic Maya Terminal Monument Dates," in Rediscovering Darwin: Evolutionary Theory and Archaeological Explanation, eds. C. Michael Barton, Geoffrey Clark, and Douglas Bamforth. Washington, D.C.: Archeological Papers of the American Anthropological Association. 7:267-290.

van Nijf, O.M. 1997. The Civic World of Professional Associations in the Roman East. Amsterdam: Gieben.

2011. "Public Space and the Political Culture of Roman Termessos," in Political Culture in the Greek City after the Classical Age, eds. R.C. Alston and Onno Van Nijf. Leuven: Peeters. 215-242.

O'Gorman, R., D.S. Wilson, and K.M. Sheldon. 2008. "For the Good of the Group? Exploring Group-level Evolutionary Adaptations using Multilevel Selection Theory." Group Dynamics-Theory Research and Practice 12 (1): 17-26.

Parkins, H. 1997. "The "Consumer City" Domesticated? The Roman City in Élite Economic Strategies", in Roman Urbanism: Beyond the Consumer City, ed. H.M. Parkins. London: Routledge. 81-108.

Plourde, Aimée. 2008. "The Origins of Prestige Goods as Honest Signals of Skill and Knowledge." Human Nature 19 (4): 374-388.

Pomeroy, Sarah B. 1997. Families in Classical and Hellenistic Greece: Representations and Realities. Oxford: Clarendon.

Price, S.R.F. 1984. Rituals and Power: The Roman Imperial Cult in Asia Minor. Cambridge: Cambridge University Press.

Quaß, Friedman. 1993. Die Honoratiorenschicht in den Städten des Griechiscen Ostens. Stuttgart: Steiner.

Raja, Rubina. 2003. "Urban Development and Built Identities: The Case of Aphrodisias in Caria in the Late Republican Period." Digressus: The Internet Journal for the Classical World Supplement 1: 86-98.

Rapaport, Amos. 1990. The Meaning of the Built Environment: A Nonverbal Communication Approach. revised. Tucson Az: University of Arizona Press.

Ratté, Christopher. 2001. "New Research on the Urban Development of Aphrodisias in Late Antiquity", in Urbanism of Western Asia Minor: The Current Status of Archaeological Research (Journal of Roman Archaeology Supplementary Series 45), ed. David Parrish. Portsmouth RI. 116-147.

Rauh, N.K. 2003. Merchants, Sailors and Pirates in the Roman World. Hertfordshire, England: Tempus Pub. Ltd.

Reger, Gary. 2003. "The Economy”, in A Companion to the Hellenistic World, ed. Andrew Erskine. Malden MA: Blackwell Publishing. 331-353.

Richerson, Peter J., Robert T. Boyd, and Joseph Heinrich. 2003. "Cultural Evolution of Human Cooperation", in Genetic and Cultural Evolution of Cooperation. Cambridge MA: MIT Press. $357-388$. 
Rigsby, Kent J. 1996. Asylia: Territorial Inviolability in the Hellenistic World. Berkeley CA: University of California Press.

Roscoe, Paul. 2009. "Social Signaling and the Organization of Small-Scale Society: The Case of Contact-Era New Guinea." Journal of Archaeological Method and Theory 16 (2): 69-116.

Rostovtzeff, Michael. 1941. The Social and Economic History of the Hellenistic World. Oxford: Clarendon Press.

Scherrer, Peter. 2001. "The Historical Topography of Ephesos", in Urbanism of Western Asia Minor: The Current Status of Archaeological Research (Journal of Roman Archaeology Supplementary Series 45), ed. David Parrish. Portsmouth RI: Journal of Roman Archaeology Series 45. 57-95.

Schwartz, H. 2001. Soll oder Haben? Die Finanzwirtschaft kleinasiatischer Städte in der römischen Kaiserzeit am Beispeil von Bithynien, Lykien and Ephesos (29 v. Chr.-284 n. Chr.). Bonn: Habelt.

Sherwin-White, A.N. 1977. "Roman Involvement in Anatolia, 167-88 в.c." Journal of Roman Studies 67: 62-75.

Simpson, Peter L.P. 1997. The Politics of Aristotle: Translation, Analysis, and Notes. Chapel Hill NC: University of North Carolina Press.

Smith, Eric Alden. 2003. "Human Cooperation: Perspectives from Behavioral Ecology", in Genetic and Cultural Evolution of Cooperation, ed. Peter Hammerstein. Cambridge MA: MIT Press. 401-428.

— lic Generosity as Costly Signaling." Evolution and Human Behavior 21: 245261.

Smith, Michael E. 2011. "Empirical Urban Theory for Archaeologists." Journal of Archaeological Method and Theory 18 (3): 167-192.

de Souza, Philip. 200o. Piracy in the Graeco-Roman World. Cambridge: Cambridge University Press.

Ten Cate, P.H.J.H. 1965. The Luwian Population Groups of Lycia and Cilicia Aspera during the Hellenistic Period. Vol. 10. Leiden: EJ Brill.

Trigger, Bruce G. 1990. "Monumental Architecture: A Thermodynamic Explanation of Symbolic Behaviour." World Archaeology 22 (2 Monuments and the Monumental): 119-132.

Trivers, R.L. 1971. “The Evolution of Reciprocal Altruism." Quarterly Review of Biology 51: 27-35.

Veblen, Thorstein. 1994 (first published 1899). The Theory of the Leisure Class. New York: Dover.

Veyne, Paul. 1976. Le Pain et le Cirque: Sociologie Historique d'un Pluralisme Politique. Paris: Seuil.

Waelkans, Marc. 2002. "The Transformation of the Public and Sacred Landscapes in 
Early Imperial Sagalassos", in Patris und Imperium, eds. Christof Berns, Henner von Hesberg, Lutgarde Vandeput, and Marc Waelkens. Leuven: Peeters. 63-75.

Wandsnider, LuAnn. 2013. "Public Buildings and Civic Benefactions in Western Rough Cilicia: Insights from Signaling Theory," in Rough Cilicia:New Archaeological and Historical Approaches, eds. Michael Hoff and Rhys Townsend. Oxford: Oxbow. 170-181.

Watts, Edward. 2006. City and School in Late Antique Athens and Alexandria. Berkeley CA: University of California Press.

Wilson, D.S., and E.O. Wilson. 2008. "Evolution 'for the Good of the Group'” American Scientist 96 (5): $380-389$.

Wörrle, M., and Paul Zanker, eds. 1995. Stadtbild und Bürgerbild im Hellenismus. München: Verlag C.H. Beck.

Zahavi, A. 1975. "Mate Selection: Selection for a Handicap." Journal of Theoretical Biology 53: 205-214.

, and Avishag Zahavi. 1997. The Handicap Principle: A Missing Piece of Darwin's Puzzle. New York: Oxford University Press.

Zanker, Paul. 1990. The Power ofImages in the Age of Augustus. Ann Arbor MI: University of Michigan Press.

Zuiderhoek, Arjan. 2005. "The Icing on the Cake: Benefactors, Economics, and Public Building in Roman Asia Minor", in Patterns in the Economy of Roman Asia Minor, eds. Stephen Mitchell and Constantina Katsari. Swansea: The Classical Press of Wales. $167-186$.

-2008. "On the Political Sociology of the Imperial Greek City." Greek, Roman and Byzantine Studies 48 (4): 417-445.

University Press. 